FESIEE

Fundación Emilio Soldevilla

para la Investigación y Desarrollo

\section{Management Letters / Cuadernos de Gestión}

journal homepage: http://www.ehu.eus/cuadernosdegestion/revista/es/

ISSN: 1131-6837 / e-ISSN: 1988-2157

\title{
Environmental sustainability and their factors in SMEs: A multiple case study of Spain and Chile
}

\section{La sostenibilidad medioambiental y sus factores en las PYMES: Un estudio de casos múltiples en España y Chile}

\author{
Francisco Villegas Pinuer ${ }^{\star}$, Leslier Valenzuela-Fernández ${ }^{\mathrm{a}}$, Joan Llonch Andreu ${ }^{\mathrm{b}}$, Pilar López Belbeze \\ a Department of Administration, School of Economics and Business, University of Chile. Av. Diagonal Paraguay 257, 8330015 Santiago, Chile - lvalenzu@fen.uchile.cl - \\ https://orcid.org/0000-0002-5817-1879 \\ ${ }^{b}$ Department of Business. Autonomous University of Barcelona. Avinguda de l'Eix Central, 08193 Bellaterra (Cerdanyola del Vallès), Spain, Barcelona - joan.llonch@uab.cat - \\ https://orcid.org/0000-0002-1624-3133 \\ c Department of Business. Autonomous University of Barcelona. Avinguda de l'Eix Central, 08193 Bellaterra (Cerdanyola del Valles), Spain, Barcelona - pilar.lopez@uab.cat - \\ https://orcid.org/0000-0002-4302-3005
}

* Corresponding author: Department of Business. Autonomous University of Barcelona. Avinguda de l'Eix Central, 08193 Bellaterra (Cerdanyola del Vallès), Spain, Barcelona - franciscojavier.villegas@e-campus.uab.cat - https://orcid.org/0000-0003-1762-0233

\section{A R T I C L E I N F O}

Received 29 September 2020, Accepted 9 May 2021

Available online 18 June 2021

DOI: $10.5295 / \mathrm{cdg} .211370 \mathrm{fv}$

JEL: Q01, L26

\begin{abstract}
A B S T R A C T
Environmental Sustainability (ES) is a growing concern for society's development while identifying companies' need to define sustainability-based strategies. Small and medium-sized enterprises (SMEs) have an essential role; generating more than $60 \%$ of employment in Europe and Latin America. Numerous research exists regarding large companies' situation on environmental topics, yet little exists on SMEs at the practical and theoretical levels. Thus, determining the variables that affect the application of ES is very relevant. This study analyzes in-depth ES factors and drivers from the SMEs' perspective, exploring the variables influencing their implementation in these companies. The methodology employed is in-depth interviews, applied to a sample of 17 SMEs in Spain and 25 SMEs in Chile. The main findings suggest that Entrepreneurial Orientation (EO), Customer Orientation (CO), and Corporate Social Responsibility (CSR) influence ES adoption in both countries, showing similarities in the driving reasons behind them, but with certain differences in their implementation (affected by institutional context influences). Furthermore, the level of knowledge affects decision-making related to the development of high-level environmental practices. Keywords: Environmental sustainability, customer orientation, corporate social responsibility, entrepreneurial orientation, SMEs.
\end{abstract}

\section{R E S U M E N}

La Sostenibilidad Medioambiental (SM) es una preocupación creciente para el desarrollo de la sociedad mientras se identifica la necesidad de que las empresas definan estrategias basadas en la sostenibilidad. Las Pequeñas y Medianas Empresas (PYMES) tienen un papel fundamental; el sector genera más del 60\% del empleo en Europa y América Latina. Existen numerosas investigaciones científicas sobre la situación de las grandes empresas en temas medioambientales, sin embargo, la literatura sobre PYMES es escasa a nivel práctico y teórico. De esta manera, determinar las variables que afectan a la aplicación de SM es muy relevante. Este estudio analiza en profundidad los factores e impulsores de la SM desde la perspectiva de las PYMES, explorando las variables que pueden influir en su implementación en estas empresas. La metodología empleada son entrevistas en profundidad, aplicadas a una muestra de 17 directores de PYMES españolas y 25 directores de PYMES Chilenas. Los principales hallazgos sugieren que la Orientación Emprendedora (OE), la Orientación al Cliente (OC) y la Responsabilidad Social Corporativa (RSC) influyen en la adopción de la SM en ambos países, manifestando similitudes en los motivos que las impulsan en ambos países, pero ciertas diferencias en su ejecución, donde influye el contexto institucional. Adicionalmente, el nivel de conocimiento afecta la toma de decisiones relacionada con el de desarrollo de practicas medioambientales de alto nivel.

Palabras clave: Sostenibilidad medioambiental, orientación al cliente, responsabilidad social corporativa, orientación emprendedora, PYMES. 


\section{INTRODUCTION}

Concern on the planet's environmental situation has become relevant to society, industry, governments, and policy-makers (Sarkis and Zhu 2018). In this way, the 17 Sustainable Development Goals (SDP) establish the Sustainable Agenda for 2030, bringing forth the relevance of environmental and social aspects (United Nations 2015). Moreover, the European Union's (EU) Sustainable Development Strategy 2020 tackles environmental issues such as sustainable transportation, sustainable consumption and production, conservation, and natural resources management (European Commission 2018).

Hence, companies have a great responsibility as the environment suffers from externalities caused by business operations, such as waste and pollution (Jiménez-Parra et al. 2018). Thus, companies must be capable of balancing their economic, social, and environmental aspects regarding their growth and development (Schaltegger and Burritt 2005), balancing the use of resources to avoid over-exploitation and ensure their continuity. Over-consumption and environmental degradation have resulted in public-calls transitioning towards a more sustainable society and economy (Adams et al. 2016), including Environmental Sustainability (ES) as a decisional factor to enhance sustainable growth (Roxas et al. 2017; Danso et al. 2019). Thusforth, understanding the factors that influence ES adoption in company strategy is primordial for implementing sustainable strategies.

The literature on environmental topics is broad, and its scope overlaps different disciplines of knowledge. Most studies focus on the situation of large companies in different sustainability application areas, such as environmental aspects (Hörisch, Ortas, Schaltegger and Álvarez 2015), production (Cohen and Muñoz 2016), customer orientation and proposal value (Urbinati et al. 2017), and Corporate Social Responsibility (Quarshie et al. 2016).

In contrast, research in SMEs is underestimated when compared to large industries (Brammer et al. 2012), yet their estimated impact on environmental pollution borders 70\% (ReyesRodríguez et al. 2016). Governments and policy-makers do not often address SMEs' responsibility in environmental degradation due to their small size. Morsing and Perrini (2009) summarize this historical problem: "the smallness of the individual SMEs is not proportional to the collective grandness of SMEs".

Nonetheless, SME literature on environmental issues has gradually grown in the last years, revealing different aspects that influence environmental practices adoption than large companies (Hörisch, Johnson and Schaltegger 2015). Manager values and perception of economic advantages (Chassé and Courrent 2018), dynamic capabilities (Eikelenboom and de Jong 2019), and stakeholders pressure (Tyler et al. 2020) are all different aspects to consider. Although SMEs' environmental literature has emerged in recent studies, there is still a lack of explorative studies that analyze their environmental situation, while considering specific countries, locations, and sectors (Bakos et al. 2020).

Thus, this research aims to contribute, by identifying the influence factors that affect ES adoption in two countries; Spain and Chile. SMEs represent $99.83 \%$ of companies in the former, generating $71.9 \%$ of employment (Ministerio de Industria Comercio y Turismo 2019) while representing $97 \%$ of all compa- nies and $70 \%$ of total jobs in the latter (Ministerio de Economia, Fomento y Turismo 2019).

In the environmental aspect, Spain is under the EU's strong environmental framework (European Commission 2018). In contrast, Chile is one South American country with a strong recently-enacted waste legislation (Ministerio del Medio Ambiente 2016). Therefore, this research compares the environmental reality of two OECD countries with different social and cultural characteristics.

To this end, relevant literature regarding ES antecedents under the framework of resource and capabilities theory was reviewed (Wernerfelt 1984, Teece et al. 1997), focusing on three factors; Customer orientation (CO), Corporate Social Responsibility (CRS), Entrepreneurial Orientation (EO). Then, multiple case studies through in-depth interviews to examine and analyze these factors' effects on ES was undertaken. This method is justified by its strength to seek new knowledge and insights to provide analytical generalization possibilities (Piekkari et al. 2009). The research findings can shed light on implementing environmental initiatives at the strategic level (Reyes-Rodríguez et al. 2016).

The article is structured in the following manner: Section 2 presents a literature review regarding the ES concept, and discusses the potential antecedents on the adoption of ES application from SMEs; Section 3 describes the methodology, the sample, the data collection process, and analysis methods; Section 4 shows the results; Section 5 presents the findings of the study and their implications for SME management and policy-maker decisions. Lastly, the limitations and future research lines are presented.

\section{THEORETICAL BACKGROUND}

\subsection{From resources, capabilities and stakeholders to SMEs Environmental Sustainability}

Sustainability is an expression of balance achievement. The concept represents "the development that meets the needs of the present without compromising the ability of future generations to meet their own needs" (World Commission on Environment and Development 1987). The central issue is the balanced and systemic integration of intra and inter-generational economic, social, and environmental performance (Geissdoerfer et al. 2017).

This research considers the environmental perspective of sustainability or the development of sustainable levels of consumption and production and the maintenance of natural capital as a complement to human capital (Goodland 1995). Their conceptualization states the balance and resilience in resource-use without affecting an ecosystem's stability (Morelli 2013). From the companies' perspective, this definition denotes the importance of resources management, which is crucial for SMEs to achieve ES.

Regarding those mentioned above, the present study uses the Resource-Based-View (RBV) and the Stakeholder theory as theoretical frameworks to understand the different factors that contribute to ES adoption. The RBV theory sustains that the competitive advantages are derived from the resources and ca- 
pabilities that are valuable, rare, imperfectly imitable, and not substitutable (Wernerfelt 1984; Barney 1991). RBV posits that competitive advantage depends on the possession of unique and differentiating resources and the ability to combine them and transform them into organizational capabilities (Wernerfelt 1984; Barney 1991, 1996).

RBV in SMEs is critical, considering their well-known limited human and financial resources (Hitchen et al. 2017) and managerial competence (Lara and Salas-Vallina 2017). Understanding ES as a potential competitive advantage, its engagement in SMEs depends on the combination of financial, technical, managerial resources and the ability to combine them (Ayuso and Navarrete-Báez 2018). Hence, RBV can be a natural base fit for the environmental dimension of sustainability.

In retrospect, stakeholder theory represents the guide to structure the companies' operation, considering the actors with a specific stake in the process (Donaldson and Preston 1995). In SMEs, stakeholder theory presents limitations in the SMEs' scope, due to prioritizing their profit margins and discretionary stakeholder's economic expectations (Sen and Cowley 2013). Their extension to social or environmental is related to their organizational capabilities (Martínez-Martínez et al. 2017). The evidence in environmental topics suggests the relevance of strategic manager behavior with their stakeholders (Hadj 2020) and the importance of stakeholder's pressure for SMEs environmental responsibility (Sáez-Martínez et al. 2016; Scuotto et al. 2020). These antecedents link the two reference frames to approach ES in SMEs.

\subsection{Environmental sustainability in SMEs: antecedents, evidence, and enablers}

All society statements have an environmental responsibility to comply, and SMEs are not the exception. However, it has not been a permanent priority in its development. Environmental management is a developing field in SMEs, where the literature has been growing recently, where strategic orientation can become crucial in their commitment to ES (Jansson et al. 2017). These strategic behaviors bring benefits to these companies. Malesios et al. (2018) found a positive association between ES practices and economic indicators, improving customer performance. Yet, how do these companies achieve these benefits?

To approach this question, it is necessary to analyze how SMEs develop and implement environmental practices. Sáez-Martínez et al. (2016) state that energy-saving, reducing waste, saving materials, saving water, recycling, and renewable energy are relevant practices to SMEs' environmental improvement. Reyes-Rodríguez et al. (2016), in a longitudinal study of 14 years, identifies and evaluates ten environmental initiatives that SME can adopt - with positive effects-, such as reducing costs and competitive advantage development; 1) environmental audit system, 2) a written environmental policy, 3) written environmental strategy, 4) regular audits of environmental goals, 5) set specific environmental goals, 6) assignation of responsibility for carrying out environmental strategy, 7) publication of a separate environmental report, 8) drawing up environmental accounts/ audit, 9) quantitative measurement of key environmental indicators, 10) Certification according to ISO 14000. Accomplishing the environmental practices with supply chain connectivity has a significant influence on environmental performance (Shibin et al. 2020). Moreover, implementing these practices implies adopting Circular Economy principles contributing to recycling, reusing, and reducing resources (Oncioiu et al. 2018).

Despite these examples, it is impossible to ignore SMEs' limitations. A literature review of 175 articles about barriers to sustainability at a worldwide level performed by Álvarez Jaramillo et al. 2019 synthesizes the most frequent obstacles such as lack of resources, the high initial capital cost in implementing measures, and lack of expertise. Moreover, this study identifies a clear imbalance in research publications production; the highest being in Europe and Asia. In contrast, Latinamerica's evidence is limited to Brazil and Uruguay. In this sense, a conditional moderator to achieve positive results is the managerial discretion of SMEs Managers/CEO/Owners as a catalyst and promoter of ES adoption in the organization (Eweje 2020).

Moreover, ES is not only an internal topic. Stakeholders exert different pressures, from customer importance to environmental legislation's rigor (Hoogendoorn et al. 2015). These examples demonstrate the broader influence factors. Henceforth, this research selected three factors that influence ES adoption: Entrepreneurial Orientation (EO), Corporate Social Responsibility (CSR), and Customer Orientation (CO).

The first factor, EO, represents a good approximation of the SMEs' behavior and their vision about the market (Avlonitis and Salavou 2007); considered a driver affecting SMEs' survival and growth (Alvarez-Torres et al. 2019). SMEs with a proactive entrepreneurial orientation stance are more inclined to environmental concerns and practices into their organizational activities (Roxas and Coetzer 2012). In lieu, when these companies have a high EO level, and present stakeholder integration, it amplifies their environmental orientation (Amankwah-Amoah et al. 2018).

The second factor, CO, is essential for SMEs; companies need to have continuous information to differentiate their offer and take market decisions (Keh et al. 2007). Hart and Dowell (2011) affirm that by connecting with their external stakeholders (customers), SMEs can get into the "voice of the environment" to pursue their environmental strategies. Therefore, CO development in SMEs is a critical source of knowledge and contributes to attending to their external stakeholders sustainably (Lee et al. 2021).

Regarding the relationship between CSR and SMEs, there is a lack of consensus about SMEs' managerial tools and opportunities derived from CSR (Russo and Perrini 2010). An example of this situation is if SMEs can benefit from positive effects as a reputational liability - considering they are less exposed than large companies- (Graafland 2018). However, the evidence in the last years considers CSR as the entrance bridge to environmental concerns and an enabler for SMEs environmental management in their production process (Hadj 2020). Moreover, the result of a systematic literature review on CSR issues on SMEs (Ortiz-Avram et al. 2018) suggests that effective CSR implementation is associated with developing and implementing environmental practices. Due to their direct association to ES, these strategic enablers will be analyzed in the following sub-sections. 


\subsection{Entrepreneurial orientation: The attitude of managers towards ES}

Entrepreneurial orientation (EO) summarizes the style, decisions and actions in developing a company's business strategy (Zhai et al. 2018). The empirical evidence suggests a positive relationship between EO and organizational performance, improving SMEs' competitiveness. For example, Covin and Lumpkin (2011) point out that an entrepreneurial approach is more receptive to external environment changes, reflected on being innovative, proactive, and having more risky business models than companies that do not adopt this approach. Covin and Miller (2014) explain that Resources-Based-Value (RBV) theory and capabilities perspective may enhance EO relationship outcomes in SMEs, as these can increase company resources and capabilities. Moreover, the study of Wales, Gupta and Mousa (2013) brings to light the importance and validity of EO as a key variable that affects different company outcomes.

Thus, there is evidence that shows that EO influences ES. Hall, Daneke and Lenox (2010) states that entrepreneurship conducts a relevant role in ES development. In this way, Marshall et al. (2015) state that a high EO level positively influences the creation of high-order ES practices. For example, Klewitz and Hansen (2014), through a systematic review based on 84 key journal articles on sustainability, found different sustainability profile behaviors based on the following attitudes: innovative, risk-taker, and proactive. In this regard, (Jansson et al. 2017) show that a proactive attitude is a condition for sustainability. In retrospect, a risk-taking attitude has no significant direct relationship to the commitment towards sustainability; this might be due to the popular vision that sustainability is an undesirable risk as there are other more profitable areas for SMEs to develop and exploit.

However, despite this evidence, the nature of EO's role and impact on sustainability remains largely undefined in terms of society. Johnson and Schaltegger (2016) mention that the scarce research about EO and the SMEs entrepreneurial profile in ES remains an open-ground for research opportunities. Hence, EO in SMEs deserves to be analyzed.

\subsection{Customer orientation: The companies' role and customer behavior on ES}

Customer orientation (CO) is a set of beliefs that consider the customer's interest first while not excluding all other stakeholders (owners, managers and employees) to develop long-term company profitability (Deshpande et al. 1993). CO is regarded as a strategic orientation that reflects the firm's ability to create and deliver superior customer value by processing market intelligence (Racela 2014), prioritizing the customer needs. Consequently, the importance of environmental aspects depends on the company's' priorities.

Evidence of this relationship suggests a positive correlation. Piercy et al. (2002) posit that customer orientation is a long-term strategy that can generate competitive advantages, which can be fundamental for ES prospection in the short and long-term. Regarding this increasing environmental concern, customers' focus is crucial to achieving a commitment towards ES, generating business opportunities (Jansson et al. 2017) and translating into performance improvement (Pekovic and Rolland 2016).

CO role in SME development is relevant; Villanueva et al. (2010) found CO essential to SMEs' success, where a company focuses on customers to know their current and future needs, and quickly respond while coordinating their actions through CO. In this regard, Peña et al. (2016) raise the importance for SMEs to have information that allows them to adjust to consumers' expectations by using market information for designing their strategies.

Regarding the potential benefits to SMEs, the relationship with ES has other considerations. Hosseininia and Ramezani (2016) research in SMEs from the food sector highlights that CO has an important effect in environmental management only if the customer has confidence in the SME. In lieu, Jansson et al. (2017) state that customer commitment to environmental strategies is essential. However, the dimensionality of customer role is an aspect that requires more information about their practical effects on SMEs' environmental consideration (Klewitz and Hansen 2014).

\subsection{Corporate social responsibility: The difficulties in their implementation}

CSR's primary purpose is to make business activity and corporate culture sustainable in the economic, social, and ecological aspects (Reverte 2016), a behavior widely associated with large companies and linked with sustainability aspects. (Melissen et al. 2018) suggest that when companies develop their social responsibility, they are more effective in contributing to sustainable development.

For SMEs, CSR has an important role in increasing competitiveness (Turyakira et al. 2014). Madueño et al. (2016) research show that CSR practices contribute to increasing competitive performance - directly and indirectly - through these organizations' ability to manage their stakeholders.

In environmental topics, Bevan and Yung (2015) explain that CSR in SMEs is a condition for sustainable environmental and economic development, and a strategic tool to compete in a business environment (Deborah et al. 2017). In this way, CSR practices' communication becomes critical for ES management success (Wu 2017). Furthermore, Quarshie et al. (2016) show that CSR affects sustainability in the Triple-Bottom-Line concept (people, profit, society). However, an SME's priority is to achieve a competitive performance rather than developing environmental practices (Herrera Madueño et al. 2016). In this sense, a rethink on how to effectively incorporate this behavior is needed, whilst considering SMEs' different realities (compared to large companies) in areas such as knowledge, resources, limitations, and cultural characteristics.

\section{METHOD}

This research uses a qualitative methodology appropriate to understand a phenomenon, describing the meaning and implications of their events (Carson and Coviello 1996) -in this case, adopting a multiple cases approach - . This method 
is recommended to gain a more in-depth understanding of a phenomenon, identifying and describing the key variables and their relationship (Eisenhardt and Graebner 2007) considering their complexity and context (Reinecke et al. 2016). Moreover, in environmental topics on SMEs, this approach was used in dimensions such as in the implementation of sustainable business practices (Caldera et al. 2018), ISO 14001 certification (Granly and Welo 2014), or environmental engagement level (Williams and Schaefer 2013).

The research's primary data was collected using in-depth interviews from SMEs in Spain (January-May 2019) and Chile (July-September 2019). In Spain's case, the sample comes from the region of Catalonia, which is the region that contributes most to Spanish GDP - 19.1\% - (Instituto Nacional de Estadística de España 2019), concentrating most of national SMEs - $22 \%$ (Idescat 2018). In Chile, companies are located in Santiago, the region with the highest contribution to Chilean GDP - 43.6\%(Banco central de Chile 2018), and has $43 \%$ of country's SMEs (SII 2017). Thus ensuring the use of similar criteria in area selection.

The SMEs definition in both countries is very similar, only differing in the annual income level. In Chile, SMEs are entities with an annual income of less than 3.21 $€^{1}$ (Ministerio de Economía 2014). In Spain, SMEs are entities with an annual income less than 50M€ (European Commission 2017).

The selection criteria of companies were: 1) Belongs to productive and service sectors, which allows the possibility of applying sustainability and CE within the business; 2) More than five employees. Respondents were recruited with the support of the Autonomous University of Barcelona in Catalonia, and University of Chile in Santiago. Hence, 18 managers from 17 SMEs in Catalonia and 29 managers from 25 SMEs from Santiago were interviewed.

These interviews are semi-structured, where patterns and topics can emerge quite freely to obtain a full conceptual description of the studied phenomenon (Glaser 1992), such as Environmental Sustainability (ES) factors. Previously, the interview content was validated by researchers of the Autonomous University of Barcelona and the University of Chile to make compatible the expressions used in both countries. All interviews (60-90 minutes length) were recorded and transcribed in Spanish. Then, translated to English by a native language professional to ensure the conceptual and dynamic equivalence of the content (Mandal 2018).

The interview structure considers general company questions (annual income, employees number, ownership structure, firms tenure) and the factors that can influence the application of ES in the business: 1) Entrepreneurial attitudes of the managers, 2) Customer factors in the business, 3) CSR and the company activities, giving space to emerging themes. The sample characteristics are presented in Table 1.

This amount correspond to the conversion of Chilean pesos to euros (at mean exchange rate of May 2020).
Table 1

Sample characteristics

\begin{tabular}{|c|c|c|c|}
\hline \multicolumn{2}{|c|}{ Managers characteristics } & \multirow{2}{*}{$\frac{\text { Spain }(\mathbf{n}=\mathbf{1 8})}{11}$} & \multirow{2}{*}{$\frac{\text { Chile }(\mathbf{n}=\mathbf{2 9})}{13}$} \\
\hline & Male & & \\
\hline & Female & 7 & 16 \\
\hline \multirow{2}{*}{$\begin{array}{l}\text { Higher } \\
\text { education }\end{array}$} & Yes & 18 & 25 \\
\hline & No & 0 & 4 \\
\hline \multirow{3}{*}{ Age } & $<35$ & 2 & 14 \\
\hline & $36-50$ & 8 & 9 \\
\hline & $>50$ & 8 & 6 \\
\hline \multicolumn{2}{|c|}{ SMEs characteristics } & Spain $(n=17)$ & Chile $(n=25)$ \\
\hline \multirow{5}{*}{$\begin{array}{l}\text { Industrial } \\
\text { sectors }\end{array}$} & Industrial & 6 & 4 \\
\hline & Commerce & 7 & 7 \\
\hline & Foodservice & 2 & 8 \\
\hline & Consulting services & 2 & 5 \\
\hline & Financial & - & 1 \\
\hline \multirow{2}{*}{$\begin{array}{l}\text { Ownership } \\
\text { structure }\end{array}$} & Familiar & 10 & 19 \\
\hline & Non-familiar & 7 & 6 \\
\hline \multirow{4}{*}{$\begin{array}{l}\text { Number of } \\
\text { Employees }\end{array}$} & $1-9$ & 2 & 12 \\
\hline & $10-49$ & 8 & 11 \\
\hline & $50-99$ & 3 & 2 \\
\hline & $>100$ & 4 & - \\
\hline \multirow{4}{*}{ Firms tenure } & $<5$ & 2 & 10 \\
\hline & $6-10$ & - & 9 \\
\hline & $11-20$ & 2 & 3 \\
\hline & $>29$ & 13 & 3 \\
\hline
\end{tabular}

Table 1 highlights the representative gender distribution, guaranteeing the managers' experiences in diversity, important in SMEs management (Williams 2013). The educational level shows similarities regarding university degrees. Regarding age, the Chilean sample has a larger younger group presence (<35 years) in comparison to Spain. This point is interesting because the available evidence suggests different perspectives - subject to age - on environmental themes (Lewis et al. 2015; Eikelenboom and de Jong 2019).

Regarding SMEs' characteristics, the sample considers different economic sectors in a relatively similar proportion in Spain and Chile to explore the spectrum of ES factors. Ownership structure shows majorly family-owned companies (61.1\%: Spain, 76\%: Chile), in lieu on the predominance of family-based SMEs globally (Mínguez-Vera and Martin 2011). In respect to tenure, the Spanish SMEs sample is older compared to Chile; the SMEs age is an interesting point but with scarce evidence of its influence on organizational environmental impact (Laforet 2013). 
The data analysis process is based on thematic analysis, considering their qualitative research suitability, especially in semi-structured methods (Alhojailan 2012). This process is worked through NVIVO11 software and identifies predefined and emerging meaning units from the interviewees' quotes. These quotes are codified to develop the codes' hierarchy structure (considering the themes and subthemes) that emerged in Spain and Chile (see Annex 1). Lastly, a clustering analysis was performed to visualize the relationship and patterns between the concepts. The research design process is detailed in Figure 1.

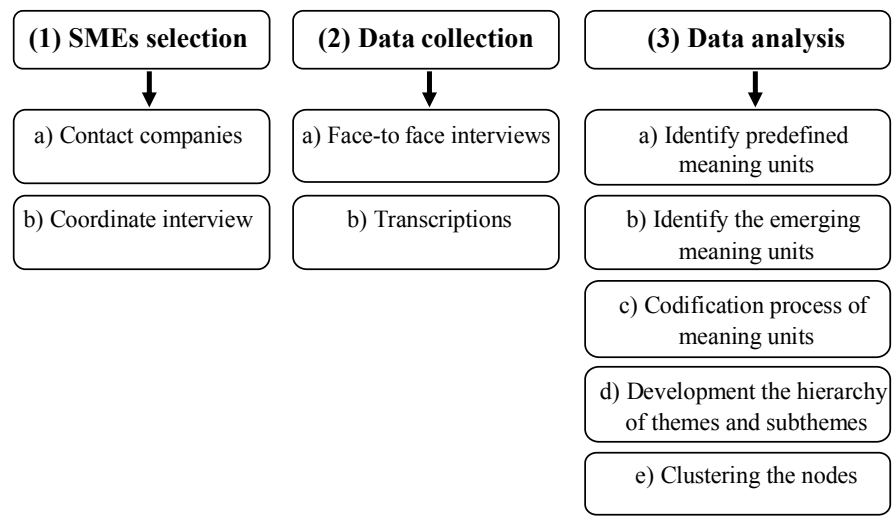

Figure 1

Research design stages

Source: Own elaboration

\section{RESULTS}

This section describes SMEs environmental practices and the three selected factors influencing Environmental Sustainability (ES) adoption: Entrepreneurial Orientation (EO), Customer Orientation (CO) and Corporate Social Responsibility (CSR); in Spain and Chile. Then, a cluster analysis of the key issues' nodes (predefined and emerged) from the study to date is presented.

\subsection{Environmental practices in Spain and Chile SMEs: A general overview}

The environmental practices show different patterns as well as common points in Spain and Chile. In Spain, most SMEs $(n=12)$ adopt environmental practices. From these companies, saving resources and waste management are their principal focus. This kind of measure represents an environmental concern in the final stage of the production process. The reasons to be environmentally sustainable are mixed. An interesting aspect is a cause-consequence relationship. Half of the companies $(n=6)$ apply environmental practices for economic and environmental reasons. However, for some companies, cost reduction is the cause, and mitigation of environmental effects is a consequence, while for other SMEs, it is the environment that matters over costs.

In Chile, $45 \%$ of SMEs ( $n=13$ ) perform environmental practices. From these companies; recycle, and disposable materials reduction of waste are the central practices. The Chilean case is similar to Spain, where the concerns are in the final stage of the production process and 'to be sustainable.' A slight difference is seen in the greater proportion of SMEs with environmental motivation. A possible reason is the lower age of the interviewees, but this requires further research. Table 2 summarizes environmental practices in both cities.

Table 2

Environmental practices in Spain and Chile

\begin{tabular}{|c|c|c|c|}
\hline $\begin{array}{c}\text { Countries/ } \\
\text { Variables }\end{array}$ & $\begin{array}{c}\text { Environmental } \\
\text { practices } \\
\text { adoption }\end{array}$ & $\begin{array}{l}\text { Environmental } \\
\text { practices most } \\
\text { adopted }\end{array}$ & $\begin{array}{l}\text { Reason to adopt } \\
\text { environmental } \\
\text { practices }\end{array}$ \\
\hline Spain & $\begin{array}{l}\text { Yes }(\mathrm{n}=12) \\
\text { No }(\mathrm{n}=6)\end{array}$ & $\begin{array}{l}\text { 1. Waste } \\
\text { management } \\
\text { control } \\
\text { 2. Water-savings } \\
\text { 3. Energy-savings } \\
\text { 4. Sustainable } \\
\text { materials use } \\
\text { 5. Materials reuse }\end{array}$ & $\begin{array}{l}\text { Economic }(n=2) \\
\text { Environmental }(n=4) \\
\text { Both }(n=6)\end{array}$ \\
\hline Chile & $\begin{array}{l}\text { Yes }(n=13) \\
\text { No }(n=16)\end{array}$ & $\begin{array}{l}\text { 1. Recycle } \\
\text { 2. Disposable } \\
\text { material } \\
\text { reduction } \\
\text { 3. Water-savings } \\
\text { 4. Material } \\
\text { recovery }\end{array}$ & $\begin{array}{l}\text { Economic }(n=1) \\
\text { Environmental }(n=7) \\
\text { Both }(n=5)\end{array}$ \\
\hline
\end{tabular}

Source: Own elaboration

\subsection{Entrepreneurial Orientation}

\subsubsection{The BUSINESS ORIGIN AND MANAgERIAL ATtITUdES IN SPAIN}

In Spain, most of the SMEs interviewed are family firms born from an opportunity (previous generation) or a personal venture to; spin on family business, reach a potential market, or new option to personal development. The CEO of an electronic company exemplifies this situation: "I have been General Director of a company that has been manufacturing in Spain for three years. I have my engineering for 15 years, and now I launched into this start-up adventure 2.5 years ago". Family firms and opportunity businesses with a consolidated position in the market tend to apply environmental practices.

SMEs managers are risk-takers in their business decisions and perspective's growth, but have more conservative-logic in the environmental aspects, privileging economic sustainability. The partner of a mechanical company states this point: "We are entrepreneurs, and we take risks. In 2008, there were 16 people, and a strong crisis has happened that of 2008 and now we are 25, that is, we have taken risks, we have invested".

However, companies with a sustainable business from the beginning are more likely to make investments. The director of a waste management company explains their case: "In every company, you have to take risks; if you do not take any risk, you do not advance". For some interviewees, the innovation atti- 
tude is key for ES. However, the possibilities are limited by the available resources and financial aid. The CEO of an electronic company states this quite well: "It is very difficult in Europe to innovate environmental responsibly. I think that in Europe we are quite stagnant. When you want to innovate, the environment does not help.".

Regarding these limitations, proactivity is an escape valve for environmental concerns. Most of the SMEs are reactive, choosing to move within their predetermined safe environment. Yet, when the business considers ES as a factor in their business conception and development, they adapt. The Quality and Environment Director of a water management company states: "The people who have to do environment and sustainability are more proactive because we have to change things".

In general, SMEs show a moderate profile (low risk-taker, medium innovativeness, low proactiveness). There is a clamor for a clear aid framework that can boost the environmental aspects of their businesses.

\subsubsection{THE BUSINESS ORIGIN AND MANAGERIAL ATTITUDES IN CHILE}

In Chile, there is variability in their origin between necessity and opportunity. Most businesses initiated by necessity are related to family businesses (sometimes inherited from the previous generation). The director of a veterinary clinic, and the owner of a food service company, states: "Is, and will always be a family business". The association between family firms and environmental practices is not clear, but it considers environmental issues in business development. A possible aspect stated in the interviews is the lack of knowledge for specific ES aspects.

SME managers are low risk-takers and show motivation on environmental topics, looking for alternatives in this field, although the financial situation limits them. The owner of a recycling product company states this aspect: "That motivation was transformed into something else that until now also nourishes us, which is more the focus of the impact that the products generate". The owner of an optical lens company gives a similar appreciation on the matter: "I have taken risks, beginning without total knowledge of the industry, we never gave up on it, thinking that we were going to do well in this project."

A moderate degree of innovation can be observed in terms of entrepreneurial attitudes, which ties strongly on customer tendency. The owner of a textile company exemplifies this situation: "We are innovators, [...]. We take good care of the first thing because if you enter any other business, you will see that the difference is abysmal".

Furthermore, SMEs have a reactive attitude on environmental themes, principally due to the pressure of their daily activities. Instead, the SME managers that apply environmental practices are characterized by their perseverance. The owner of a sanitary products company represents this spirit: "The issue of being persistent in environmental themes is crucial to be motivated all the time trying to be present. All problems have a solution."

Chilean SMEs represent a conservative profile (low risk-taker, low innovation, reactive), where ES becomes a personal and not structured desire of SMEs.

\subsection{Customer orientation}

\subsubsection{The Client Role in Spain: How to inform and COMMUNICATE}

In Spain, information is the way that connects companies to customers. In this case, companies do not deliver much information to customers about environmental practices. The General Director of a textile company states this situation: "I believe that the final consumer has no information, and that is what should be done, raise awareness". SMEs argue that it is necessary to have a bi-directional relationship to achieve a real connection between companies and customers to improve the environmental performance situation. The owner of a textile company explains his vision: "We believe that this can help us, the proof is that we are making efforts communicating this issue. Making more sustainable products, making recycled articles, is a market niche in which we are".

In retrospect, the interviewees point out that there are different customer types based on ES commitment and business behavior. The manager of an industrial company states their importance for the business: "When a client raises a question or need, we transform it into a challenge for us, to satisfy it. Therefore, based on the inputs we have from customers, we generate our strategy". There are customers' segments more involved and informed about if companies realize environmental practices. However, some transactional clients do not value these aspects. The Acquisitions Manager of a pharmaceutical laboratory exemplified this issue: "There are clients who deliver the material, and we only pack it. There are clients that we only do full service" Moreover, SMEs deepen that if their SMEs stakeholders - as clients - do not exert environmental pressure, the incentives to adopt certifications such as ISO14000 or environmental practices are not taken as there is no reward in economic aspects. These examples point out that ES is not too important for the customer from their perspectives and appeal instead to customer responsibility and interests.

Another relevant aspect mentioned is communication; SMEs express their concern about developing the message, both in substance and form, towards the customer. The CEO of a clothing company expresses this consideration: "You have to know how to communicate well what you are doing, what you have, why you have it. This is the most important thing, why we have, not only what we have". Linked to this, the interviewees express their concern about the communication effects. Some companies take advantage of their image improvement, transforming their environmental practices into a marketing strategy without a real commitment to ES. The CEO of a textile company states this point clearly: "There are some sustainable fashion brands that sin a bit of this, which is seeing that maybe it is a good marketing strategy".

\subsubsection{The Client ROLE in Chile: LACK Of information AND VISIBILITY}

In the Chilean case, the situation reveals different problems in terms of information compared to Spain. The delivered information to the customers about environmental themes is scarce 
or null. The owner of a shoe company states this issue: "In terms of communication, I lack how to synthesize what we are carrying out, which is what I tell you, how to communicate our environmental practices in our process".

Companies do make an effort to detect their client's needs. The owner of a restaurant gives an example of this: "We try to keep up with the requirements of our public in our area". From this process, SMEs identify a problematic relationship with the environment if they do not give ES importance. Thus, it becomes highly probable that SMEs do not consider environmental subjects within their value proposition as it holds little relevance to make sales.

In this way, the interviewees coincide in heterogeneous behavior and customer commitment, yet the lack of client pressure for ES of products and services has become common. The Operations Manager of a consulting company states: "It is very reactive, as already. I want this, and we do this. There is no topic to go to propose; there is little". Thus for SMEs, it does not seem necessary to obtain environmental certifications due to this perspective.

Communication is a relevant aspect for companies, as it is considered the first step to achieve ES. The owner of a food service company highlights this importance: "It is fundamental to interact with the day-to-day clients, which was something we did not always have before". In this line, the clarity and scope of the message is the starting point. The owner of a craft company explains this situation: "It has to be fundamental. What we are transmitting is what is closer to the person".

However, this communication must be reinforced in two points. First, through the relationship with the community. The owner of a restaurant emphasizes this aspect: "We have been in the same neighborhood that we have always been, so we know all the people in the area, we are neighbors for years, and that shows." Second, the visibility of sustainable actions and the corresponding media to communicate and enhance ES diffusion. The owner of a coffee company shares this concern: "Today we do not communicate with them as much. We do not have the form to communicate with them well in the next three months. Today we communicate with them by uploading a photo". Communication perception becomes a critical factor.

\subsection{Corporate social responsibility}

\subsubsection{THE LACK OF EMPLOYEE INVOLVEMENT IN CORPORATE SOCIAL ACTIVITIES IN SPAIN}

CSR is a complex concept for Spanish SMEs, presenting different degrees of understanding. The partner of the mechanical company states their vision: "We consider that a part of our benefits can be invested in society. However, there has to be no obligation for it to be done". The Communications Director of a chemical company states another perspective: "I am a supporter of removing the social word because responsibility must be social. We live in society; there is no other type of responsibility". A common point from the interviewees is the null allusion to environmental themes as a part of CSR. However, an explanation for this phenomenon is the presence of waste management legislation. A manager of an industrial company states this point: "The environmental legislation determines the operation rules. I believe that the regulation is intended to accompany us to how we should be to face the environmental challenges".

Regarding those mentioned above, the SMEs' CSR activities are focused on involvement with society. We identify that most of the mentioned activities are related to charity and the community's delivery of products by discussing this issue. When excluding the SME process (approached by the legislation) and discerning the environmental practices related to companies' internal processes, a rising problem is employees' low degree involvement. The owner of an Eco-hostel corroborates this idea: "Personally the employees do not get involved, that is a topic that we should take, and it cannot be that they do not get involved". The interviewees express the importance of having a strong employee team to help transmit these attitudes throughout the firm and thus bring it to become an organizational behavior. The Administration Manager of a plastic confection company shares their experience: "We have a team of susceptible people who know how to transmit very well, and we can convince very quickly everyone who becomes part of the team".

\subsubsection{Corporate Social Responsibility in Chile: A timid APPROACH TO ENVIRONMENTAL ISSUES}

Similar to Spain, CSR in Chile considers a broad spectrum of conceptualizations. The range considers donations, charity, education or opportunities. A concrete example of this variety is the owner of a shoe company: "I feel that my social responsibility is my relationship with my internal client, the transparency", and the Advisor of a Financial Institution: "Nowadays, we are not talking as much about CSR in specific. Today we are like encompassing more in sustainability as a concept." Other companies recognize that does not include CSR development. The manager of a consulting company expresses their reality: "I would say that there is no lifting of Social Responsibility and our effects on the community, of internal policies of benefits for workers, nothing."

Interestingly, CSR has an extension in ES aspects. This extension does not have common patterns, showing different perspectives, shown in Table 3.

Table 3

Interviewees quotes about environmental practices within CSR

\begin{tabular}{ll}
\hline \multicolumn{1}{c}{ Interviewees } & \multicolumn{1}{c}{$\begin{array}{c}\text { Corporate Social Responsibility activities } \\
\text { related to environmental themes or practices }\end{array}$} \\
\hline $\begin{array}{l}\text { Owner of a coffee } \\
\text { company }\end{array}$ & $\begin{array}{l}\text { "We are trying to do a sustainable meal. } \\
\text { All the money raised will be donated to the } \\
\text { community." }\end{array}$ \\
\hline & $\begin{array}{l}\text { "Today we are working on generating a } \\
\text { volunteer free plan, that is, you can choose } \\
\text { what to help and when to help it, depending } \\
\text { on the cause that motivates you. I believe that } \\
\text { corporate environmental volunteering once } \\
\text { a year Today is not enough for anything. I } \\
\text { cosmetic company a that the consumer who nowadays } \\
\text { double-clicks, no longer believe it." }\end{array}$ \\
\hline
\end{tabular}

Owner of a

foodservice company "We plan to do recycling activities." 
Independently of these activities related to environmental topics, their communication level towards the society and customers is scarce. A commercial company manager explains: "Our activities are completely internal in the company, nothing has been manifested to the community". Although some companies spread these activities, a recurring issue is a passive interest in these themes when SMEs communicate them. The partner of a mechanical company points out: "We communicate our environmental responsibility, but our stakeholders are not very interested either, as they do not get much on the subject." These examples evidence different problems and perspectives for ES.

\subsection{Other emerging topics}

\subsubsection{DECISION-MAKING PROCESS}

SMEs take decisions continuously, establishing priorities in their business. In this sense, how articulating their strategy directly affects the incorporation of environmental issues and developing practices. The hierarchy, decentralization level, business decisions unit (uni-personal, partners, collective), and stakeholders' involvement are relevant aspects. These elements emerge with similar connotations in Spain and Chile. The coor- dination between strategic decisions and their extension in environmental practices as tactics show interesting considerations.

\subsubsection{LEARNING: FORMATION AND TRAINING}

A theme that emerged through the different topics approached in the interviews is the formation of SMEs. It is common for SMEs to declare their lack of technical skills and knowledge in approaching environmental aspects, materials management, and second-life waste. These limitations affect the organization (managers and their employees) transversally, and the concern is the absence of mechanisms to improve the knowledge. Historically, SMEs have more relevant concerns about their survival and ability to sustain themselves in a highly competitive market. Therefore, their efforts and motivation in the business core diminish the possibilities to apply environmental practices. However, observations show a slightly higher level of knowledge in Spanish SMEs when compared to Chilean ones, reflected in waste management aspects. From this perspective, learning is presented as a potential factor that enables environmental practices.

Considering the aforementioned, Table 4 summarizes the structured and emerged aspects in Spain and Chile.

Table 4

Comparative summary of environmental sustainability factors

\begin{tabular}{|c|c|c|}
\hline Regions / Topics & Spain & Chile \\
\hline Entrepreneurial Orientation & $\begin{array}{l}\text { 1. Family firms: environmental proclive. } \\
\text { 2. Little investment on environmental themes; } \\
\text { scarce financial aids. } \\
\text { 3. A moderate entrepreneurial profile (little risk- } \\
\text { taker, low innovation, reactive). }\end{array}$ & $\begin{array}{l}\text { 1. Family firms: slightly tendency to environmental } \\
\text { themes } \\
\text { 2. Little investment on environmental themes; } \\
\text { scarce financial aids. } \\
3 \text { A conservative entrepreneurial profile (little risk- } \\
\text { taker, low innovation, reactive). }\end{array}$ \\
\hline Customer Orientation & $\begin{array}{l}\text { 1. Low information degree about environmental } \\
\text { practices to the customers. } \\
\text { 2. Low customer involvement on environmental } \\
\text { issues; traduce in scarce environmental } \\
\text { certifications as ISO norms. } \\
\text { 3. Deficiencies in the message development about } \\
\text { environmental practices. }\end{array}$ & $\begin{array}{l}\text { 1. Scarce information degree about environmental } \\
\text { practices to the customers. } \\
\text { 2. Scarce visibility of sustainable actions developed } \\
\text { by SMEs. } \\
\text { 3. Null communication of environmental practices. }\end{array}$ \\
\hline Corporate Social Responsibility & $\begin{array}{l}\text { 1. Environmental practices not considered in CSR } \\
\text { (are associated with environmental legislation). } \\
\text { 2. Low employees involvement in internal } \\
\text { environmental practices }\end{array}$ & $\begin{array}{l}\text { 1. Environmental practices as part of CSR; lower } \\
\text { effects and recurrence. } \\
\text { 2. Scarce communication of the environmental } \\
\text { practices to their stakeholders. }\end{array}$ \\
\hline Emerged themes & $\begin{array}{l}\text { 1. Decision-making process: centralized and lower } \\
\text { consideration to environmental themes in } \\
\text { strategic decisions. } \\
\text { 2. Medium degree of technical knowledge and skills } \\
\text { to incorporate environmental issues. }\end{array}$ & $\begin{array}{l}\text { 1. Decision-making process: centralized and null } \\
\text { considerations to environmental themes in } \\
\text { strategic decisions } 3 \text {. } \\
\text { 2. Lower degree of technical knowledge and skills to } \\
\text { incorporate environmental issues. }\end{array}$ \\
\hline
\end{tabular}

Source: Own elaboration 
These results show the Spanish and Chilean situation regarding ES adoption factors, where Spain is one step forward compared to Chile. The pending general debt is a major consideration in the business processes' initial stages and more tangible communication.

\subsection{Clusterization of the three-factor nodes and their sub-themes}

\subsubsection{Spain ClUSterization MaP}

In the Spanish case, ES application denotes a clear first cluster, where CO and CSR are the most associated variables to ES (see Figure 2). Moreover, corporate activities with a sustainable focus must be aligned, where communication has a fundamental role in customer relationships. The second cluster associates EO and business origin, where ES is a consideration from the beginning, according to the companies' possibilities. The involvement of the employees is crucial to their application. The third cluster considers the information, an essential aspect that is a weakness in ES communication; the challenge is integrating this information with the organizational activities. The fourth cluster is another side of the previous cluster, the relevance of ES for the customers. The two furthest clusters of ES reflect the business's actual situation, the entrepreneurial attitude, and the decision-making process of their decisions where ES is not considered close to their priorities; however, it can have influenced by rigorous environmental legislation.

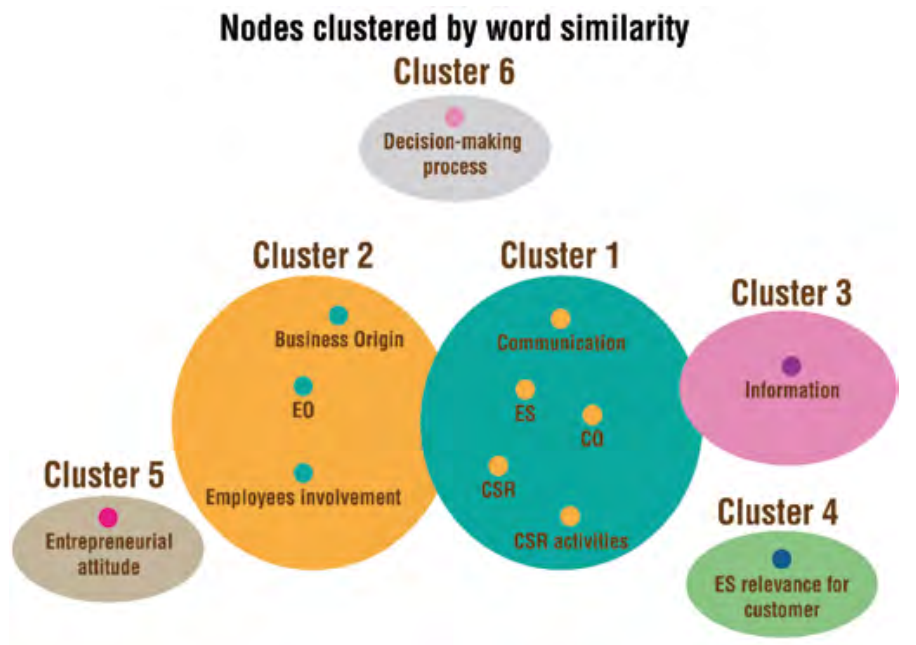

Figure 2

Spain clusterization of ES antecedents

Source: Own elaboration

The points of the same colour belong to the same cluster

Cluster 1: Customer Orientation (CO), Corporate Social Responsibility (CSR), Communication, CSR activities, Cluster 2: Entrepreneurial orientation (EO), Business origin, employees involvement. Cluster 3: Information. Cluster 4: Environmental sustainable relevance for customer. Cluster 5: Entrepreneurial attitude. Cluster 6: Decisionmaking process.

\subsubsection{Chile Clusterization MAP}

Clusterization is different in Chile (see Figure 3). The first cluster considers EO and CSR as the most associated variables to ES. Moreover, the entrepreneurial attitude and motivation highlight the importance of the SME managers' conviction, and the corporate activities with ES must be aligned. The second cluster is the CO and the information, establishing the relevance of this aspect to improve customer perception, generating a virtuous circle with SMEs. The third cluster is the decision-making process, distant from the companies decisions; the personal valuation is in the same line of the business origin, the fourth cluster. The last clusters are the relevance of ES for customers and communication; these two inter-related aspects are a great doubt of SMEs in the ES implementation process.

SME managers' experiences with ES and their implementation drivers in Spain and Chile show two common factors; 1) the absence of ES in the SMEs decision-making process and 2) the lack of ES relevance for customers. These factors reveal a lack of integration between the stakeholders of society. However, these obstacles and limitations have proper characteristics, considering the specific reality of the regions: 1) In Spain, communication with the customers is a relevant subject; the relationship between mechanisms and messages is essential. In Chile, this problem is a step back. The information is a critical factor, 2) in Spain, ES adoption has a relevant component in the employees' involvement with the company's actions. In Chile, this point has similarities, but the managers' motivation has more relevance regarding whether they have social or normative pressure.

\section{Nodes clustered by word similarity}

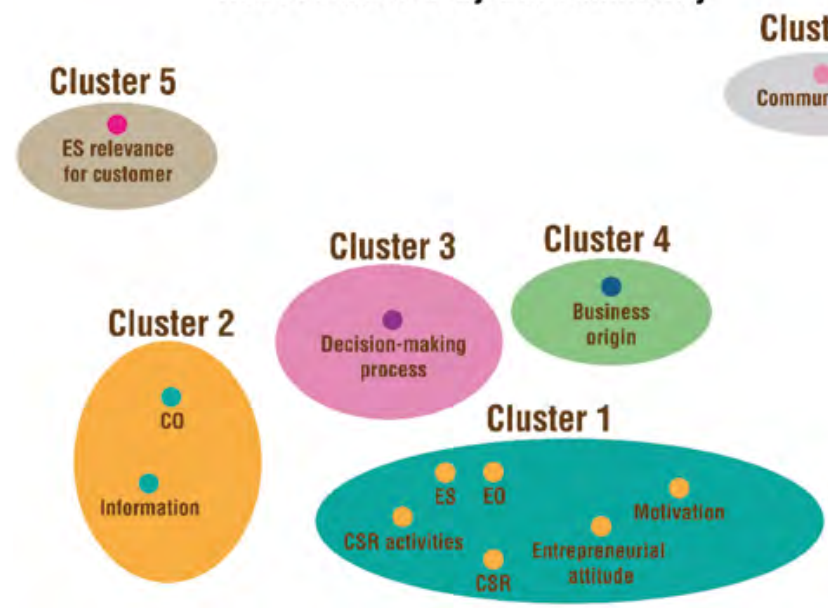

Figure 3

Chile clusterization of ES antecedents

Source: Own elaboration

The points of the same colour belong to the same cluster

Cluster 1: Entrepreneurial orientation, Entrepreneurial attitude, motivation, Corporate Social Responsibility, CSR activities. Cluster 2: Customer orientation, information Cluster 3: Decision-making process. Cluster 4: Business origin. Cluster 5: Environmental Sustainable relevance for the customer. Cluster 6: Communication. 


\section{DISCUSSION AND CONCLUSIONS}

\subsection{Discussion}

These research findings explain how EO, CO and CSR affect SMEs ES adoption in Spain and Chile. Additionally, two emerging factors are highlighted: decision-making process and learning (and their potential to influence ES). Based on these findings, we discuss results and offer theoretical and practical insights that contribute and support the implementation and leveraging of environmentally sustainable practices in SMEs.

Through this work, differences in the factors mentioned above are evident between Spain and Chile in the implementation of ES. Hence, analyzing the managers' characteristics does not show relevant differences in gender, manager's-age and educational level between the cities (Roxas et al. 2017; Eikelenboom and de Jong 2019). Nonetheless, considering the study characteristics requires specific detailed sector research to shed light on their potential effects.

At the SMEs characteristics level, family firms show a positive environmental commitment tendency in both cities (more prevalent in Spain than Chile). The ownership structure was studied by López-Pérez et al. (2017) that found a moderation relationship with environmental practices. Family firms show more sensitivity to these themes but are based on Agency Theory principles. Moreover, Adomako et al. (2019) found that EO has a positive effect on family firms. However, the performance benefits are major in nonfamily firms. Therefore, it requires more evidence on family firms in future research to assert this affirmation fully. In the case of firms' tenure, Spain's older sample has a slight tendency to greater environmental concern. The evidence is consistent with Doluca et al. (2018), which shows a strong effect on long-term ES orientation.

In lieu to the works of Marshall et al. (2015) and AmankwahAmoah et al. (2018), we can observe that EO exerts a positive influence on ES, reflecting the concerns on environmental issues. The importance of innovative and risk-taking attitudes in their EO is relevant to implementing ES in their strategy, presenting certain nuances in Spain and Chile exist). In the former, SMEs show a moderate profile (low risk-taker, medium innovativeness, medium proactiveness), while the latter shows a conservative profile (low risk-taker, low innovation, reactive). An example of this difference is the tendency to realize little investment in environmental aspects (for economic or environmental reasons). These differences are similar to Gherib and Berger-Douce (2012) cross-cultural research that compares French and Tunisian SMEs (findings show a more risker profile in French SMEs). These attitudes allow the visualization of ES more as business options, hence adopting new technologies or generating collaboration with other firms.

In this line, an emerging topic is the decision-making process. In both cases, environmental aspects are not incorporated in the strategic decisions - explained by their day-to-day priorities - and do not directly benefit their companies. DiVito and Bohnsack (2017) research suggests that EO influences ES in the decision-making process. SMEs managers need to assume the change in an agent role, internalizing ES in the organization (Wiesner et al. 2018). Nevertheless, this situation is endorsed by their different barriers: lack of financial resources, lack of time, risks associated with implementing a sustainable practice, current regulations (Caldera et al. 2019), and the importance of SME manager as agent role. SMEs require local governments' support through advisory to achieve sustainable development (Ayuso and Navarrete-Báez 2018).

In the case of $\mathrm{CO}$, common patterns can be observed between Spain and Chile. In both, SMEs consider the customers' passive attitude that does not exert pressure regarding environmental subjects. However, their managers understand the necessity of incorporating ES in their communication. In Spain, the principal problem is message development (how to engage their customers). Some companies realize the effort, desisting when denoting the lack of relevance in the decisional buyer-process. This process requires governmental aid and public funds that promote this behavior on SMEs. While in Chile, the problem is communication. SMEs that perform environmental practices that do not communicate these activities do not consider it relevant and prefer to communicate other messages related to commercial activities. These results are not unrelated to the evidence on low customer engagement in companies' ES and their dilemma for SMEs. When they are under customer pressure, they will actively search and capture customer input regarding environmental concerns (Chen and Liu 2020), and tend to engage in ES (Lee et al. 2019). In this sense, customer and stakeholders' pro-environmental attitudes trigger SMEs to develop environmental measures (Triguero et al. 2013). The reasoning is that, if customer and external society demands ES - as a consequence of CO-SMEs will respond to this sensitivity (Jansson et al. 2017). However, the relationship between message development and effective communication requires a more in-depth understanding.

From this factor, knowledge appears as a limitant from SMEs perspective; there is a clear recognition of the lack of knowledge about environmental topics that affect adopting high-level environmental practices. Spain presents a higher knowledge degree than Chile, applying it in their production process. However, it is not enough, hence reflected in the absence of circular practices as reducing or reuse, relevant for ES (Ünal et al. 2019). This capability is an enabler for developing and integrating environmentally sustainable practices in SMEs (Roxas and Chadee 2016). The knowledge extension is an edge to investigate properly; technical knowledge about materials, supply chain process, and waste management (Yacob et al. 2019).

In retrospect, CSR is largely misunderstood in SMEs, as it is mostly associated with social activities (charities, donations). Nevertheless, there are some differences between the cities. In Spain, considering the lack of high-level sustainable practices, low-level sustainable practices as recycling are mandatory under environmental legislation. Therefore, they are not considered within the CSR conception. When companies understand their importance as corporate citizens in Spain, it allows them to see the externalities and negative effects not considered in their production process. While in Chile, some SMEs apply recycling activities as a part of CSR and contribute to the community. SMEs do not have declared obligations at the moment (considering environmental legislation in development) (Ministerio del Medio Ambiente 2016) as CSR activities are strongly related to the pos- 
sibility of developing ES aspects in business (Reyes-Rodríguez et al. 2016). This situation is normal for large companies and differs from small companies due to their operational impact and public exposure. This difference affects the content, nature, and extent of their CSR activities (Dias et al. 2019). However, CSR's inclusion of environmental aspects is a discussion topic in SMEs, with evidence in different ways. (Dincer and Dincer 2013) qualitative research found that SME managers incorporate CSR environmental issues, showing a general concern for the environment. The comparative study in the food industry of Colovic et al. (2019) about CSR adoption between France and Lithuanian SMEs shows incorporating environmental practices as natural and essential in their operations; the difference is the major adoption of environmental certifications in French SMEs. Nevertheless, a common point is the high environmental standard in the industry. This point is relevant to study, considering that CSR activities have a mandatory nature in Europe, whereas it has a voluntary character in Latin America (Hernández Pajares and Moneva 2018).

\subsection{Theoretical contributions}

This research contributes to the limited understanding of SMEs environmental externalities (Stoian and Gilman 2017), critical for sustainable and economic development (Bevan and Yung 2015). Through multiple case studies, light can be shed on the ES factors adoption in Spanish and Chilean SMEs. Thus, this contribution to the literature is threefold. Firstly, this study extends the ES literature about the role of EO, CO, and CSR from managers' perspectives in two different institutional settings; a developed economy like Spain, and a transition economy as Chile. Secondly, exposure of two emerging themes; 1) decision-making process and their relation with SMEs stakeholders, and 2) knowledge about environmental themes as materials and resources, presenting their difference between the countries. These aspects require more study at the local level, can complement and enhance ES (Crovini et al. 2020). Finally, the comparative analysis demonstrates the relevance of institutional context and the environmental legislation's potential effects in these mentioned aspects, especially CSR (Graafland and Smid 2017).

\subsection{Managerial implications}

The research findings show how SME managers in Spain and Chile can act environmentally responsible. This research demonstrates the relevance of innovative, proactive, and risk-taking attitudes by SME managers to implement ES in their strategy; necessary to complement with a subsidy plan and advisory by local governments to motivate and convince SMEs of the potential benefits of ES. Additionally, managers need to understand the importance of communicating their environmental practices independently of their stakeholders' pressure, such as their clients. ES is a bi-directional process; the message development and the appropriate communication channels are crucial to engaging with stakeholders. As a result, SMEs can give superior value to the market (Racela 2014) by proposing value that adopts a downstream vision in a sustainable manner (Urbinati et al. 2017). For
SMEs, the involvement of ES is an evolving process that depends on the companies, stakeholders, and institutional conditions of the countries. Instead of waiting for the ES imposition, SMEs should proactively incorporate into their business operations and process.

\section{LIMITATIONS AND FUTURE RESEARCH}

Despite the contributions, this research has limitations. This study investigated SMEs ES based on two countries' multiple cases, limiting the findings' generalization capacity. Therefore, the results must be read mindfully, considering the sample size. For this reason, future research could benefit, study other countries, cultures, and specific economic sectors. The industries have different aspects and limitations that need to be considered in future research to enrich the empirical perspective.

Regarding the findings, future studies can be extended to analyze the learning orientation in SMEs, considering their knowledge necessity and decision-making process - taking into account the institutional and contextual factors-. SMEs do not have pressure in environmental sustainability topics, and deepening the priorities, mechanism, and resources to learn and adapt to the environment can be relevant for ES adoption.

Concerning the data, this investigation is based on SMEs managers' responses; it can be interesting for future research, to collect the appraisals from other stakeholders, such as suppliers, clients, and/or local community, to contrast the different ES views. Additionally, future research would contemplate the influence of the time in the results, to verify, refute or extend the obtained results.

\section{ACKNOWLEDGMENTS}

The first author was financially supported by the National Agency for Research and Development (ANID)/Scholarship Program/DOCTORADO BECAS CHILE/2018-72190184 doctoral grant. We would like to thank the anonymous reviewers and the associate editor for their helpful comments in the review process. Maximiliano Velasco, an English-language professional reviewer, corrected the English in the development process of this article, and Pablo Lillo, a professional digital content creator, generates the article figures.

\section{REFERENCES}

Adams, R., Jeanrenaud, S., Bessant, J., Denyer, D., and Overy, P., 2016. Sustainability-oriented Innovation: A Systematic Review. International Journal of Management Reviews, 18 (2), 180-205.

Adomako, S., Amankwah-Amoah, J., Danso, A., Konadu, R., and Owusu-Agyei, S., 2019. Environmental sustainability orientation and performance of family and nonfamily firms. Business Strategy and the Environment, 28 (6), 1250-1259.

Alhojailan, M.I., 2012. Thematic Analysis : A Critical Review of Its Process and Evaluation. WEI International European Academic Conference Proceedings. 
Alvarez-Torres, F.J., Lopez-Torres, G.C., and Schiuma, G., 2019. Linking entrepreneurial orientation to SMEs' performance: Implications for entrepreneurship universities. Management Decision, 57 (12), 3364-3386.

Álvarez Jaramillo, J., Zartha Sossa, J.W., and Orozco Mendoza, G.L., 2019. Barriers to sustainability for small and medium enterprises in the framework of sustainable development-Literature review. Business Strategy and the Environment, 28 (4), 512-524.

Amankwah-Amoah, J., Danso, A., and Adomako, S., 2018. Entrepreneurial orientation, environmental sustainability and new venture performance: does stakeholder integration matter? Business Strategy and the Environment, 28 (1), 79-87.

Avlonitis, G.J. and Salavou, H.E., 2007. Entrepreneurial orientation of SMEs, product innovativeness, and performance. Journal of Business Research, 60 (5), 566-575.

Ayuso, S. and Navarrete-Báez, F.E., 2018. How Does Entrepreneurial and International Orientation Influence SMEs' Commitment to Sustainable Development? Empirical Evidence from Spain and Mexico. Corporate Social Responsibility and Environmental Management, 25 (1), 80-94.

Bakos, J., Siu, M., Orengo, A., and Kasiri, N., 2020. An analysis of environmental sustainability in small \& medium-sized enterprises: Patterns and trends. Business Strategy and the Environment, 29 (3), 1285-1296.

Banco central de Chile, 2018. PIB regional - Banco Central de Chile [online]. Banco Central de Chile. Available from: http://www.bcentral.cl/pib-regional [Accessed 23 May 2020].

Barney, J., 1991. Firm Resources and Sustained Competitive Advantage. Journal of Management, 17 (1), 99-120.

Barney, J.B., 1996. The Resource-Based Theory of the Firm. Organization Science, 7 (5), 469-469.

Bevan, E.A.M. and Yung, P., 2015. Implementation of corporate social responsibility in Australian construction SMEs. Engineering, Construction and Architectural Management, 22 (3), 295-311.

Brammer, S., Hoejmose, S., and Marchant, K., 2012. Environmental Management in SMEs in the UK: Practices, Pressures and Perceived Benefits. Business Strategy and the Environment, 21 (7), 423-434.

Caldera, H.T.S., Desha, C., and Dawes, L., 2018. Exploring the characteristics of sustainable business practice in small and medium-sized enterprises: Experiences from the Australian manufacturing industry. Journal of Cleaner Production, 177, 338-349.

Caldera, H.T.S., Desha, C., and Dawes, L., 2019. Evaluating the enablers and barriers for successful implementation of sustainable business practice in 'lean' SMEs. Journal of Cleaner Production, 218, 575-590.

Carson, D. and Coviello, N., 1996. Qualitative research issues at the marketing/entrepreneurship interface. Marketing Intelligence \& Planning, 14 (6), 51-58.

Chassé, S. and Courrent, J.M., 2018. Linking owner-managers' personal sustainability behaviors and corporate practices in SMEs: The moderating roles of perceived advantages and environmental hostility. Business Ethics, 27 (2), 127-143.

Chen, J. and Liu, L., 2020. Customer participation, and green product innovation in SMEs: The mediating role of opportunity recognition and exploitation. Journal of Business Research, 119, 151-162.

Cohen, B. and Muñoz, P., 2016. Sharing cities and sustainable consumption and production: towards an integrated framework. Journal of Cleaner Production, 134, 87-97.

Colovic, A., Henneron, S., Huettinger, M., and Kazlauskaite, R., 2019. Corporate social responsibility and SMEs: Evidence from a transition and a developed economy. European Business Review, 31 (5), 785-810.
Covin, J.G. and Lumpkin, G.T., 2011. Entrepreneurial Orientation Theory and Research: Reflections on a Needed Construct. Entrepreneurship Theory and Practice, 35 (5), 855-872.

Covin, J.G. and Miller, D., 2014. International Entrepreneurial Orientation: Conceptual Considerations, Research Themes, Measurement Issues, and Future Research Directions. Entrepreneurship Theory and Practice, 38 (1), 11-44.

Crovini, C., Santoro, G., and Ossola, G., 2020. Rethinking risk management in entrepreneurial SMEs: towards the integration with the decision-making process. Management Decision.

Danso, A., Adomako, S., Amankwah-Amoah, J., Owusu-Agyei, S., and Konadu, R., 2019. Environmental sustainability orientation, competitive strategy and financial performance. Business Strategy and the Environment, 28 (5), 885-895.

Deborah, M.B., K, W.R.E., Love, M.C., and Grace, A.C., 2017. Corporate Social Responsibility as a Determinant of Sustainability of Small Medium Enterprises ( SMEs ). Covenant Journal of Business \& Social Sciences (CJBSS), 8 (2), 76-86.

Deshpande, R., Farley, J.U., and Webster, F.E., 1993. Corporate Culture, Customer Orientation, and Innovativeness in Japanese Firms: A Quadrad Analysis. Journal of Marketing, 57 (1), 23.

Dias, A., Rodrigues, L.L., Craig, R., and Neves, M.E., 2019. Corporate social responsibility disclosure in small and medium-sized entities and large companies. Social Responsibility Journal, 15 (2), 137-154.

Dincer, B. and Dincer, C., 2013. Corporate social responsibility decisions: a dilemma for SME executives? Social Responsibility Journal, 9 (2), 177-187.

DiVito, L. and Bohnsack, R., 2017. Entrepreneurial orientation and its effect on sustainability decision tradeoffs: The case of sustainable fashion firms. Journal of Business Venturing, 32 (5), 569-587.

Doluca, H., Wagner, M., and Block, J., 2018. Sustainability and Environmental Behaviour in Family Firms: A Longitudinal Analysis of Environment-Related Activities, Innovation and Performance. Business Strategy and the Environment, 27 (1), 152-172.

Donaldson, T. and Preston, L.E., 1995. the Stakeholder Theory of the Corporation: Concepts, Evidence, and Implications. Academy of Management Review, 20 (1), 65-91.

Eikelenboom, M. and de Jong, G., 2019. The impact of dynamic capabilities on the sustainability performance of SMEs. Journal of Cleaner Production, 235, 1360-1370.

Eisenhardt, K.M. and Graebner, M.E., 2007. Theory building from cases: Opportunities and challenges. Academy of Management Journal, 50 (1), 25-32.

European Commission, 2017. What is an SME? | Internal Market, Industry, Entrepreneurship and SMEs [online]. European Commission. Available from: https://ec.europa.eu/growth/smes/business-friendly-environment/sme-definition_en [Accessed 31 May 2020].

European Commission, 2018. EU Sustainable Development Strategy - Environment - European Commission [online]. Available from: papers3:// publication/uuid/BFAA0FF6-7D3E-4425-8E56-6F46D44430D9 [Accessed 15 Jun 2020].

Eweje, G., 2020. Proactive environmental and social strategies in a small- to medium-sized company: A case study of a Japanese SME. Business Strategy and the Environment, 29 (7), 2927-2938.

Geissdoerfer, M., Savaget, P., Bocken, N.M.P., and Hultink, E.J., 2017. The Circular Economy - A new sustainability paradigm? Journal of Cleaner Production, 143, 757-768.

Gherib, J. and Berger-Douce, S., 2012. Entrepreneurial Profile and Environmental Commitment of SMEs: A Comparative Analysis in Franceand in Tunisia. International Business Research, 5 (7).

Glaser, B.G., 1992. Emergence vs forcing: Basics of grounded theory analysis. Sociology Press. 
Gómez Villanueva, J., Llonch Andreu, J., and Rialp Criado, J., 2010. Orientación estratégica, innovación y resultados en PYMES de nueva creación: El rol del marketing. Cuadernos de Gestion, 10 (ESPECIAL), 85-110.

Goodland, R., 1995. The concept of environmental sustainability. Annual Review of Ecology and Systematics.

Graafland, J., 2018. Does Corporate Social Responsibility Put Reputation at Risk by Inviting Activist Targeting? An Empirical Test among European SMEs. Corporate Social Responsibility and Environmental Management, 25 (1), 1-13.

Graafland, J. and Smid, H., 2017. Reconsidering the relevance of social license pressure and government regulation for environmental performance of European SMEs. Journal of Cleaner Production, 141, 967-977.

Granly, B.M. and Welo, T., 2014. EMS and sustainability: Experiences with ISO 14001 and Eco-Lighthouse in Norwegian metal processing SMEs. Journal of Cleaner Production, 64, 194-204.

Hadj, T.B., 2020. Effects of corporate social responsibility towards stakeholders and environmental management on responsible innovation and competitiveness. Journal of Cleaner Production, 250, 119490.

Hall, J.K., Daneke, G.A., and Lenox, M.J., 2010. Sustainable development and entrepreneurship: Past contributions and future directions. Journal of Business Venturing, 25 (5), 439-448.

Hart, S.L. and Dowell, G., 2011. A natural-resource-based view of the firm: Fifteen years after. Journal of Management, 37 (5), 1464-1479.

Hernandez Pajares, J. and Moneva, J.M., 2018. Corporate social responsibility performance and sustainability reporting in SMEs: an analysis of owner-managers' perceptions. International Journal of Sustainable Economy, 10 (4), 405-420.

Herrera Madueño, J., Larrán Jorge, M., Martínez Conesa, I., and Martínez-Martínez, D., 2016. Relationship between corporate social responsibility and competitive performance in Spanish SMEs: Empirical evidence from a stakeholders' perspective. BRQ Business Research Quarterly, 19 (1), 55-72.

Hitchen, E.L., Nylund, P.A., Ferràs, X., and Mussons, S., 2017. Social media: open innovation in SMEs finds new support. Journal of Business Strategy, 38 (3), 21-29.

Hoogendoorn, B., Guerra, D., and van der Zwan, P., 2015. What drives environmental practices of SMEs? Small Business Economics, 44 (4), 759-781.

Hörisch, J., Johnson, M.P., and Schaltegger, S., 2015. Implementation of Sustainability Management and Company Size: A Knowledge-Based View. Business Strategy and the Environment, 24 (8), 765-779.

Hörisch, J., Ortas, E., Schaltegger, S., and Álvarez, I., 2015. Environmental effects of sustainability management tools: An empirical analysis of large companies. Ecological Economics, 120, 241-249.

Hosseininia, G. and Ramezani, A., 2016. Factors influencing sustainable entrepreneurship in small and medium-sized enterprises in Iran: A case study of food industry. Sustainability (Switzerland), 8 (10), 1010.

Idescat, 2018. Idescat. Anuario estadístico de Cataluña. Empresas y establecimientos a 1 de enero. Por sectores de actividad y número de asalariados [online]. Available from: https://www.idescat.cat/pub/?id=aec\&n=975\&lang=es [Accessed 31 May 2020].

Instituto Nacional de Estadística de España, 2019. España en cifras 2019 [online]. Available from: https://www.ine.es/prodyser/espa_cifras/2019/31/ [Accessed 23 May 2020].

Jansson, J., Nilsson, J., Modig, F., and Hed Vall, G., 2017. Commitment to Sustainability in Small and Medium-Sized Enterprises: The Influence of Strategic Orientations and Management Values. Business Strategy and the Environment, 26 (1), 69-83.
Jiménez-Parra, B., Alonso-Martínez, D., and Godos-Díez, J.-L., 2018. The influence of corporate social responsibility on air pollution: Analysis of environmental regulation and eco-innovation effects. Corporate Social Responsibility and Environmental Management, 25 (6), 1363-1375.

Johnson, M.P. and Schaltegger, S., 2016. Two Decades of Sustainability Management Tools for SMEs: How Far Have We Come? Journal of Small Business Management, 54 (2), 481-505.

Keh, H.T., Nguyen, T.T.M., and Ng, H.P., 2007. The effects of entrepreneurial orientation and marketing information on the performance of SMEs. Journal of Business Venturing, 22 (4), 592-611.

Klewitz, J. and Hansen, E.G., 2014. Sustainability-oriented innovation of SMEs: a systematic review. Journal of Cleaner Production, 65, 5775.

Laforet, S., 2013. Organizational innovation outcomes in SMEs: Effects of age, size, and sector. Journal of World Business, 48 (4), 490-502.

Lara, F.J. and Salas-Vallina, A., 2017. Managerial competencies, innovation and engagement in SMEs: The mediating role of organisational learning. Journal of Business Research, 79, 152-160.

Lee, C.M.J., Che-Ha, N., and Syed Alwi, S.F., 2021. Service customer orientation and social sustainability: The case of small medium enterprises. Journal of Business Research, 122, 751-760.

Lee, E., Jo, S.H., and Jeong, H., 2019. Environmental management in small and medium enterprises: the role of customer orientation and firm performance. Journal of Business and Industrial Marketing, 34 (8), 1779-1790.

Lewis, K. V., Cassells, S., and Roxas, H., 2015. SMEs and the Potential for A Collaborative Path to Environmental Responsibility. Business Strategy and the Environment, 24 (8), 750-764.

López-Pérez, M.E., Melero, I., and Javier Sese, F., 2017. Management for Sustainable Development and Its Impact on Firm Value in the SME Context: Does Size Matter? Business Strategy and the Environment, 26 (7), 985-999.

Malesios, C., Skouloudis, A., Dey, P.K., Abdelaziz, F. Ben, Kantartzis, A., and Evangelinos, K., 2018. Impact of small- and medium-sized enterprises sustainability practices and performance on economic growth from a managerial perspective: Modeling considerations and empirical analysis results. Business Strategy and the Environment, 27 (7), 960-972.

Mandal, P.C., 2018. Translation in Qualitative Studies: Evaluation Criteria and Equivalence. The Qualitative Report, 23 (10), 2529.

Marshall, D., McCarthy, L., McGrath, P., and Claudy, M., 2015. Going above and beyond: how sustainability culture and entrepreneurial orientation drive social sustainability supply chain practice adoption. Supply Chain Management: An International Journal, 20 (4), 434-454.

Martínez-Martínez, D., Madueño, J.H., Jorge, M.L., and Sancho, M.P.L., 2017. The strategic nature of corporate social responsibility in SMEs: A multiple mediator analysis. Industrial Management and Data Systems, 117 (1), 2-31.

Melissen, F., Mzembe, A.N., Idemudia, U., and Novakovic, Y., 2018. Institutional Antecedents of the Corporate Social Responsibility Narrative in the Developing World Context: Implications for Sustainable Development. Business Strategy and the Environment, 27 (6), 657-676.

Mínguez-Vera, A. and Martin, A., 2011. Gender and management on spanish SMEs: An empirical analysis. International Journal of $\mathrm{Hu}$ man Resource Management, 22 (14), 2852-2873.

Ministerio de Economia, Fomento y Turismo, 2019. Quinta Encuesta Longitudinal de Empresas (ELE5) - Ministerio de Economía, Fomento y Turismo [online]. Available from: https://www.economia. gob.cl/2019/03/12/quinta-encuesta-longitudinal-de-empresas-ele5. htm [Accessed 7 Apr 2020]. 
Ministerio de Economía, 2014. Antecedentes para la revisión de los criterios de clasificación del Estatuto Pyme. Santiago.

Ministerio de Industria - Comercio y Turismo, 2019. Cifras PYME [online]. Portal PYME. Available from: http://www.ipyme.org/esES/publicaciones/Paginas/estadisticaspyme.aspx [Accessed $8 \mathrm{Apr}$ 2020].

Ministerio del Medio Ambiente, 2016. Ley 20.920 Gestión de residuos, la responsabilidad extendida del productor y fomento al reciclaje.

Morelli, J., 2013. Environmental Sustainability: A Definition for Environmental Professionals. Journal of Environmental Sustainability, 1 (1), 1-10.

Morsing, M. and Perrini, F., 2009. CSR in SMEs: do SMEs matter for the CSR agenda? Business Ethics: A European Review, 18 (1), 1-6.

Oncioiu, I., Căpuşneanu, S., Türkeș, M., Topor, D., Constantin, D.-M., Marin-Pantelescu, A., and Ștefan Hint, M., 2018. The Sustainability of Romanian SMEs and Their Involvement in the Circular Economy. Sustainability, 10 (8), 2761.

Ortiz-Avram, D., Domnanovich, J., Kronenberg, C., and Scholz, M., 2018. Exploring the integration of corporate social responsibility into the strategies of small- and medium-sized enterprises: A systematic literature review. Journal of Cleaner Production.

Pekovic, S. and Rolland, S., 2016. Customer orientation and firm's business performance. European Journal of Marketing, 50 (12), 21622191.

Piekkari, R., Welch, C., and Paavilainen, E., 2009. The Case Study as Disciplinary Convention. Organizational Research Methods, 12 (3), 567-589.

Piercy, N.F., Harris, L.C., and Lane, N., 2002. Market orientation and retail operatives' expectations. Journal of Business Research, 55 (4), 261-273.

Polo Peña, A.I., Frías Jamilena, D.M., and Rodríguez Molina, M.Á., 2016. The Effect of Customer Orientation on Smaller Sized Service Firms and on the Market: A Multilevel Application Embracing Firms and Customers. Journal of Small Business Management, 54 (2), 566-581.

Quarshie, A.M., Salmi, A., and Leuschner, R., 2016. Sustainability and corporate social responsibility in supply chains: The state of research in supply chain management and business ethics journals. Journal of Purchasing and Supply Management, 22 (2), 82-97.

Racela, O.C., 2014. Customer Orientation, Innovation Competencies, and Firm Performance: A Proposed Conceptual Model. Procedia Social and Behavioral Sciences, 148, 16-23.

Reinecke, J., Arnold, D.G., and Palazzo, G., 2016. Qualitative Methods in Business Ethics, Corporate Responsibility, and Sustainability Research. Business Ethics Quarterly.

Reverte, C., 2016. Corporate social responsibility disclosure and market valuation: evidence from Spanish listed firms. Review of Managerial Science, 10 (2), 411-435.

Reyes-Rodríguez, J.F., Ulhøi, J.P., and Madsen, H., 2016. Corporate Environmental Sustainability in Danish SMEs: A Longitudinal Study of Motivators, Initiatives, and Strategic Effects. Corporate Social Responsibility and Environmental Management, 23 (4), 193 212.

Roxas, B., Ashill, N., and Chadee, D., 2017. Effects of Entrepreneurial and Environmental Sustainability Orientations on Firm Performance: A Study of Small Businesses in the Philippines. Journal of Small Business Management, 55, 163-178.

Roxas, B. and Chadee, D., 2016. Knowledge management view of environmental sustainability in manufacturing SMEs in the Philippines. Knowledge Management Research and Practice, 14 (4), 514-524.

Roxas, B. and Coetzer, A., 2012. Institutional Environment, Managerial Attitudes and Environmental Sustainability Orientation of Small Firms. Journal of Business Ethics, 111 (4), 461-476.
Russo, A. and Perrini, F., 2010. Investigating stakeholder theory and social capital: CSR in large firms and SMEs. Journal of Business Ethics, 91 (2), 207-221.

Sáez-Martínez, F.J., Díaz-García, C., and González-Moreno, Á., 2016. Factors promoting environmental responsibility in European SMEs: The effect on performance. Sustainability (Switzerland), 8 (9), 898.

Sarkis, J. and Zhu, Q., 2018. Environmental sustainability and production: taking the road less travelled. International Journal of Production Research, 56 (1-2), 743-759.

Schaltegger, S. and Burritt, R., 2005. The International Yearbook of Environmental and Resource Economics 2005/2006: A Survey of Current Issues. Cheltenham: Edwar Elgar Publishing.

Scuotto, V., Alexeis, G.P., Valentina, C., and Elisa, G., 2020. Do stakeholder capabilities promote sustainable business innovation in small and medium-sized enterprises? Evidence from Italy. Journal of Business Research, 119, 131-141.

Sen, S. and Cowley, J., 2013. The Relevance of Stakeholder Theory and Social Capital Theory in the Context of CSR in SMEs: An Australian Perspective. Journal of Business Ethics, 118 (2), 413-427.

Shibin, K.T., Dubey, R., Gunasekaran, A., Hazen, B., Roubaud, D., Gupta, S., and Foropon, C., 2020. Examining sustainable supply chain management of SMEs using resource based view and institutional theory. Annals of Operations Research, 290 (1-2), 301-326.

SII, 2017. SII | Servicio de Impuestos Internos [online]. Estadisticas de empres Servicio de Impuestos Internos. Available from: http://www. sii.cl/sobre_el_sii/estadisticas_de_empresas.html\%0Ahttp://www. sii.cl/valores_y_fechas/dolar/dolar2019.htm\%0Ahttp://www.sii.cl/ sobre_el_sii/estadisticas_de_empresas.html\%0Ahttp://www.sii.cl/ valores_y_fechas/dolar/dolar2018.htm\%0Ahttp://www.sii. [Accessed 31 May 2020].

Stoian, C. and Gilman, M., 2017. Corporate Social Responsibility That "Pays": A Strategic Approach to CSR for SMEs. Journal of Small Business Management, 55 (1), 5-31.

Teece, D.J., Pisano, G., and Shuen, A., 1997. Dynamic capabilities and strategic management. Strategic Management Journal, 18 (7), 509533.

Triguero, A., Moreno-Mondéjar, L., and Davia, M.A., 2013. Drivers of different types of eco-innovation in European SMEs. Ecological Economics, 92, 25-33.

Turyakira, P., Venter, E., and Smith, E., 2014. The impact of corporate social responsibility factors on the competitiveness of small and medium-sized enterprises. South African Journal of Economic and Management Sciences, 17 (2), 157-172.

Tyler, B., Lahneman, B., Beukel, K., Cerrato, D., Minciullo, M., Spielmann, N., and Discua Cruz, A., 2020. SME Managers' Perceptions of Competitive Pressure and the Adoption of Environmental Practices in Fragmented Industries: A Multi-Country Study in the Wine Industry. Organization \& Environment, 33 (3), 437463.

Ünal, E., Urbinati, A., and Chiaroni, D., 2019. Managerial practices for designing circular economy business models: The case of an Italian SME in the office supply industry. Journal of Manufacturing Technology Management, 30 (3), 561-589.

United Nations, 2015. Transforming Our World, the 2030 Agenda for Sustainable Development. General Assembly Resolution A/RES/70/1.

Urbinati, A., Chiaroni, D., and Chiesa, V., 2017. Towards a new taxonomy of circular economy business models. Journal of Cleaner Production, 168, 487-498.

Wales, W.J., Gupta, V.K., and Mousa, F.T., 2013. Empirical research on entrepreneurial orientation: An assessment and suggestions for future research. International Small Business Journal, 31 (4), 357-383.

Wernerfelt, B., 1984. A resource-based view of the firm. Strategic Management Journal, 5 (2), 171-180. 
Wiesner, R., Chadee, D., and Best, P., 2018. Managing Change Toward Environmental Sustainability: A Conceptual Model in Small and Medium Enterprises. Organization \& Environment, 31 (2), 152-177.

Williams, D., 2013. Gender and the Internationalization of SMES. Journal of International Business Research, 12 (1), 133.

Williams, S. and Schaefer, A., 2013. Small and Medium-Sized Enterprises and Sustainability: Managers' Values and Engagement with Environmental and Climate Change Issues. Business Strategy and the Environment, 22 (3), 173-186.

World Commission on Environment and Development, 1987. Brundtland Report: Our Common Future. United Nations.
Wu, G.-C., 2017. Effects of Socially Responsible Supplier Development and Sustainability-Oriented Innovation on Sustainable Development: Empirical Evidence from SMEs. Corporate Social Responsibility and Environmental Management, 24 (6), 661-675.

Yacob, P., Wong, L.S., and Khor, S.C., 2019. An empirical investigation of green initiatives and environmental sustainability for manufacturing SMEs. Journal of Manufacturing Technology Management, 30 (1), 2-25.

Zhai, Y.M., Sun, W.Q., Tsai, S.B., Wang, Z., Zhao, Y., and Chen, Q., 2018. An empirical study on entrepreneurial orientation, absorptive capacity, and SMEs' innovation performance: A sustainable perspective. Sustainability (Switzerland), 10 (2), 314. 